\title{
KONSEP DASAR EVALUASI HASIL BELAJAR SISWA DI SEKOLAH
}

\author{
Iqra \\ PascasarjanaUniversitas Muhammadiyah Surakarta (UMS) \\ Email: iqradompu93@gmail.com
}

\begin{abstract}
Abstrak
Tujuan penelitian ini adalah untuk mengetahui kemampuan siswa pada ranah kognitif, afektif dan psikomotorik materi; mengetahui perbedaaan kemampuan antara siswa yang satu dengan siswa yang lain pada setiap ranah penilaian; serta keterkaitan antara kemampuan ranah afektif dengan kemampuan ranah kognitif dan kemampuan ranah psikomotorik. Penelitian ini menggunakan metode kualitatif deskriptif. Penelitian kualitatif sebagai prosedur penelitian yang menghasilkan data deskriptif. Alasan menggunakan pendekatan ini karena peneliti ingin mengetahui dampak dari hasil evaluasi. Evaluasi sebagai suatu kegiatan mengumpulkan data dan informasi mengenai kemampuan belajar siswa, Evaluasi bertujuan untuk mengetahui tingkat pencapaian siswa dalam suatu proses pembelajaran, sekaligus untuk memahami siswa sampai sejauh mana dapat memberikan bantuan terhadap kekurangan-kekurangan siswa, Sedangkan fungsi evaluasi untuk membantu proses, kemajuan dan perkembangan hasil belajar peserta didik secara berkesinambungan, dan sekaligus dapat mengetahui kemampuan dan kelemahan siswa pada bidang studi tertentu.
\end{abstract}

Kata Kunci: Evaluasi, Belajar, Siswa.

\section{PENDAHULUAN}

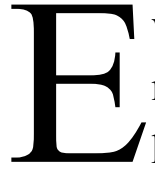

valuasi dapat mendorong siswa untuk lebih giat belajar secara terus menerus dan juga mendorong guru untuk lebih meningkatkan

kualitas proses pembelajaran serta mendorong sekolah untuk lebih meningkatkan fasilitas dan kualitas belajar siswa (Mahirah, 2017). Evaluasi adalah sebuah hal yang sangat urgen dalam dunia pendidikan, karena pada dasarnya evaluasi untuk mengukur sejauh mana hasil dan kegiatan atau proses belajar mengajar dan administrasi dalam pendidikan tersebut, agar bisa diperbaiki sehingga bisa tercapai apa yang menjadi tujuan pendidikan. 
Setiap orang yang melakukan suatu kegiatan akan selalu ingin tahu hasil dari kegiatan yang dilakukannya. Seringkali pula, orang yang melakukan kegiatan tersebut, berkeinginan mengetahui baik atau buruknya kegiatan yang dilakukannya. Siswa dan guru merupakan orang-orang yang terlibat dalam kegiatan pembelajaran, tentu mereka juga berkeinginan mengetahui proses dan hasil kegiatan pembelajaran yang dilakukan. untuk menyediakan informasi tentang baik atau buruknya proses dan hasil kegiatan pembelajaran, maka seorang guru harus menyelenggarakan evaluasi. Kegiatan evaluasi yang dilakukan guru mencakup evaluasi hasil belajar dan evaluasi pembelajaran sekaligus (Academia, 2017). Maka dengan demikian evaluasi hasil belajar dan pembelajaran peserta didik dalam sekolah sebagai lembaga pendidikan formal merupakan langkah yang menunjukan jalan kesuksesan peserta didik untuk mengetahui bagaimana keefektifan proses belajar anak dalam sekolah dan agar bisa mengukur segala kekurangannya.

\section{Tinjauan Definisi Tentang Evaluasi}

Merujuk penjelasan para pakar pendidikan, terdapat ragam devinisi evaluasi dinataranya;

1. Bloom et (1971). "evalution, as we see it, is the systematic collection of evidence to determine whether in fact certain changes are taking place in the learnesrs as weel a to determine the amount or degree of change in individual students" Artinya: evaluasi, sebagai mana kita lihat, adalah pengumpulan kenyataan secara sistematis untuk menetapkan apakah dalam kenyataannya terjadi perubahan dalam diri siswa dan menetapkan sejauh mana tingkat perubahan dalam pribadi siswa.

2. Stufflebeam et.al (1971). Evaluasi merupakan proses mengambarkan, memperoleh, dan menyajikan informasi yang berguna untuk menilai alternatif keputusan.

3. Suke Silverius (1991). "Profesional judgment or a process that allows one to make a judgmen about the desirability or value of something. "Artinya: pertimbangan profesional atau suatu proses yang 
memungkinkan seseorang membuat pertimbangan tentang daya tarik atau nilai sesuatu (Suke Silverius, 1991).

Selain istilah evaluasi seperti yang tercantum dalam definisi diatas, kita dapati pula istilah pengukuran dan penilaian. Ketiga istilah tersebut pada umumnya cenderung diartikan sama (tidak dibedakan). Padahal sebenarnya ketiga istilah tersebut tidak sama artinya, setidak-tidaknya ada kaitan antara ketiga istilah tersebut. Coba perhatikan contoh-contoh berikut: a) Apabila ada orang yang akan memberikan tongkat kepada kita, dan kita disuruh memilih anatara dua tongkat yang tidak sama panjangnya, maka tentu saja kita akan memilih yang panjang. Kita tidak memilih yang pendek kecuali ada alasan yang sangat khusus. b) Pasar, merupakan suatu tempat bertembunya orang-orang yang akan menjual dan membeli. Sebelum menentukan barang yang akan dibelinya, seorang pembeli akan memilih dahulu mana barang yang lebih baik menurut ukuranya. Apabila ia ingin membeli jeruk, dipilihnya jeruk yang besar, kuning, kulitnya halus. Semuanya itu dipertimbangkan karena menurut pengalaman sebelumnya, jenis jeruk-jeruk yang demikian ini rasanya akan manis. Sedangkan jeruk yang masih kecil, hijau dan kulitnya agak kasar, biasanya masam rasanya. Dari contoh-contoh diatas ini dapat disimpulkan bahwa sebelumnya menentukan pilihan, kita mengadakan penilaian terhaap benda-benda yang dipilih. Dalam contoh pertama kita memilih mana tongkat yang lebih panjang, sedangkan dalam contoh yang kedua menentukan dengan perkiaan kita atas jeruk yang baik yaitu yang rasanya manis (Daryanto, 2001).

\section{Tujuan dan Fungsi Evaluasi Hasil Belajar Siswa}

\section{Tujuan Evaluasi}

Dalam setiap kegiatan evaluasi, langkah pertama yang harus diperhatikan adalah tujuan evaluasi. Penentuan tujuan evaluasi sangat bergantung pada jenis evaluasi yang digunakan. Tujuan evaluasi ada yang bersifat umum dan ada yang bersifat khusus. Jika tujuan evaluasi bersifat umum, maka tujuan tersebut perlu diperinci menjadi tujuan khusus, 
sehingga dapat menentukan guru dalam menyusun soal atau mengembangkan instrumen evaluasi lainnya. Ada dua cara yang dapat ditempuh guru untuk merumuskan tujuan evaluasi yang bersifat khusus. Pertama, melakukan perencian proses mental yang akan dievaluasi. Cara pertama berhubungan dengan luas pengetahuan sesauai dengan silabus mata pelajaran dan cara kedua berhubungan dengan jenjang pengetahuan, seperti dikembangkan oleh Bloom dkk.

Perlu diketahui bahwa evaluasi banyak digunakan dalam berbagai bidang dan kegiatan, anatara lain dalam kegiatan bimbingan dan kegiatan penyuluhan, supervisi, seleksi, dan pembelajaran. Setiap bidang atau kegiatan tersebut mempunyai tujuan yang berbeda. Dalam kegiatan bimbingan, tujuan evaluasi adalah untuk menentukan keadaan suatu situasi pendidikan atau pembelajaran, sehingga dapat diusahakan langkah-langkah perbaikan untuk meningkatkan mutupendidikan disekolah. Dalam kegiatan seleksi, tujuan evaluasi adalah untuk mengetahui tingkat pengetahuan, keterampilan, sikap dan nilai-nilai peserta didik untuk jenis pekerjaan, jabatan atau pendidikan tertentu. Menurut Kellough dalam sweringen (2006) tujuan peinilain adalah untuk membantu belajar peserta didik, mengidentifikasi kekuatan dan kelemahan peserta didik, menilai fektivitas strategi pembelajaran, menilai dan meningkatkan efektivitas program kurikulum, menilai dan meningkatkan efektivitas pembelajaran menyediakan data yang membantu dalam membuat keputusan, komunikasi dan melibatkan orang tua peserta didik (Zainal Arifin, 2014).

\section{Fungsi Evaluasi}

Dengan mengetahuai manfaat evaluasi ditinjau dari berbagai segi dalam sistem pendidikan, maka dengan cara lain dapat dikatakan bahwa fungsi evaluasi ada beberapa hal:

a. Evaluasi berfungsi selektif. Dengan cara mengadakan evaluasi guru mempunyai cara untuk mengadakan seleksi terhadap siswanya. Seleksi sendiri mempunyai tujuan antar lain, untuk memilih siswa yang dapat diterima disekolah, untuk memilih siswa yang dapat naikkelas atau 
tingkat berikutnya, untuk memilih siswa yang seharusnya mendapat beasiswa, untuk memilih siswa yang sudah berhak meninggalkan sekolah dan sebagainya.

b. Evaluasi berfungsi sebagai penempatan. Sistem baru yang kini banyak dipopulerkan dinegara barat, adalah sistem belajar sendiri. Blajar sendiri dapat dilakukan dengan cara mempelajari sebuah paket belajar, baik itu berbentuk modul maupun paket belajr yag lain.

c. Evaluasi berfungsi diagnostik. Apabila alat yang digunakan dalam evaluasi cukup memenuhi persyaratan, maka dengan melihat hasilnya, guru akan mengetahui kelemahan siswa. Disamping itu diketahui pula sebab musabab kelemahan itu. Jadi dengan mengadakan evaluasi, sebenarnya guru mengadakan diagnosis kepada siswa tentang kebaikan dan kelemahannya. Dengan diketahuinya sebab-sebab kelemahan ini, akan lebih mudah dicari cara untuk mengatasi.

d. Evaluasi berfungsi sebagai pengukuran kebehasilan. Fungsi ke empat dari efaluasi ini dimaksudkan untuk mengetahui sejauh mana suatu program berhasil diterapkan. Keberhasilan program ditentukan oleh beberapa faktor yaitufaktor guru, metode mengajar kurikulum, sarana dan sistem kurikulum (Daryanyo, 2001).

\section{Tinjaun Tentang Hasil Belajar Siswa}

Terkait dengan hasil belajar Purwanto mengatakan bahwa hasil belajar adalah untuk mengukur tujuan pelajaran yang telah diajarkan atau mengukur kemampuan siswa setelah mendapatkan pengalaman belajar suatu mata pelajaran tertentu. Kemudian bagi Brigg mengatakan bahwa hasil belajar adalah semua kecakapan dan hasil yang didapatkan melalui kegiatan belajar mengajar di sekolah yang dinyatakan dengan angka-angka dan nilai bersumber dari tes pengukuran hasil belajar.Sedangkan Sudijono mengemukakan bahwa hasil belajar merupakan gambaran tentang kemajuan atau perkembangan siswa, sejak dari awal mula mengikuti program pendidikan sampai pada saat mereka mengakhiri program pendidikan yang ditempuhnya. Dari Gagne menetapkan ketegori hasil belajar kedalam lima 
macam, yakni: (1) Informasi verbal, adalah kemampuan yang dimiliki seseorang guna menyampaikan fakta- fakta atau peristiwa dengan cara lisan atau tulisan, (2) Keterampilan intelektual, adalah suatu kemampuan yang dapat menyebabkan seseorang bisa membedakan, menggabungkan, mentabulasi, menganalisis, menggolong-golongkan, mengkuantifikasikan benda, kejadian dan lambang, (3) Keterampilan motorik, adalah keterampilan seseorang untuk dapat melakukan sesuatu gerakan dalam banyak gerakan yang terorganisasi, (4) Strategi kognitif, adalah kemampuan seseorang perihal teknik berfikir, pendekatan- pendekatan dalam menganalisis dan pemecahan masalah dan, (5) Sikap, adalah kemampuan bagi seseorang untuk menerima atau menolak terhadap sesuatu objek tertentu berdasarkan penilaian tentang objek tersebut.

Berdasarkan gambaran di atas, dapat disimpulkan bahwa hasil belajar dapat diketahui setelah siswa mendapatkan pengalaman belajar dan mengalami perubahan tingkah laku. Dengan adanya suatu perubahan yang terjadi pada siswa sesudah mendapatkan pengalaman belajarnya dan dengan demikian disebutkan sebagai hasil belajar. Kemudian dapat memberikan suatu kejelasan bentuk dan berbagai macam hasil belajar yang diterima oleh siswa setelah ikut serta dalam proses pembelajaran. Maka dengan demikian hasil belajar itu bisa tercapai melalui berbagai bentuk dan merupakan suatu kemampuan terhadap diri seseorang. Dari Gagne mengatakan bahwa hasil belajar dapat dihubungkan dengan terjadinya suatu perubahan tingkah laku seseorang dalam kecenderungan terhadap keterampilan dalam proses perkembangannya yang terjadi setelah proses belajar dengan cara memberikan perlakuan dan latihan tertentu. Sedangkan Sukardi dan Maramis menyatakan bahwa hasil belajar merupakan perubahan tingkah laku yang terjadi pada siswa sebagai akibat dari proses pendidikan yang direncanakan dan perubahan tingkah laku itu sesuai dengan tujuan yang tercantum dalam kurikulum yang berlaku.

Dalam kaitan dengan hasil belajar, Brigg mengatakan bahwa hasil belajar adalah seluruh kecakapan dan hasilnya yang diraih melalui proses 
belajar mengajar di sekolah yang ditetapkan dengan angka-angka dan diukur berdasarkan tes hasil belajar. Sedangkan Sukardi dan Maramis mengatakan bahwa mengukur merupakan penerapkan alat ukur terhadap objek tertentu. Besaran-besaran angka yang didapat barulah memperoleh makna apabila dibandingkan hasil pengukuran dengan suatu patokan tertentu. Menurut Romiszowski hasil belajar memiliki tiga kategori, yaitu: kognitif, psikomotorik, dan afektif. Sedangkan Syamsudin dalam Ramli Abdullah mengungkapkan bahwa perbuatan dan hasil belajar ditentukan dalam bentuk: (1) pertambahan materi pengetahuan yang berupa fakta, (2) penguasaan bentuk psikomotorik, dan (3) Perbekalan dalam kaitannya dengan kepribadian. Berdasarkan uraian di atas, dapat ditegaskan bahwa terdapat persamaan dan perbedaan mengenai prinsip taksonomi. Berkenaan dengan persamaannya bahwa hasil belajar adalah suatu tujuan yang dicapai setelah mengalami pengalaman dalam kegiatan pembelajaran, sedangkan perbedaannya bahwa prinsip-prinsip taksonomi itu sangat berguna dalam merancang tujuan khusus pembelajaran, dan ini merupakan menifestasi dari hasil belajar di lembaga pendidikan (Ramli Abdullah. 2015). Evaluasi hasil belajar siswa dalam tulisan ini menilai dan mengevaluasi dari segi penilaian secara umum yakni di lihat dari faktor dan pengukuran kognitif, afektif dan, psikomotorik.

\section{Pengukuran Ranah Kognitif}

Salah satu atau objek atau sasaran evaluasi hasil belajar adalah aspek atau ranah kognitif. Ranah kognitif adalah ranah yang mencakup kegiatan mental (otak). Hasil belajar ranah ini dikembangkan oleh benjamin . Bloom dkk. Yang dituangkan dalam mereka yang berjudul "Taxonomomy of educational Objectives, Handbook I: Cognitive Domain". Menurut Benjamin S. Bloom dkk (1956), segala upaya yang menyangkut aktivitas otak adalah termasuk dalam ranah kognitif. Ranah kognitif berhubungan dengan kemampuan berfikir, termasuk didalamnya kemampuan menghafal, memahami, mngaplikasi, meganalisis, menyintesis, dan kemampuan mengevaluasi (Sukiman, 2012). 


\section{Pengukuran Ranah Afektif}

Menurit Daryanto (2001) cakupan pengukuran ranah afektif meliputi lima jenjang kemampuan.

a. Menerima (receiving). Jenjang ini berhubungan dengan kesediaan atau kemauan siswa untuk ikut dalam fenomena atau stimulus khusus (kegiatan dalam kelas, musik, baca buku dan sebagaianya).

b. Menjawab (responding). Kemampuan ini bertalian dengan partisipasi siswa. Pada tingkat ini, siswa tidak hanya menghadiri suatu fenomena tertentu tetapi juga mereaksi terhadapnya dengan salah satu cara.

c. Menilai (Valuing). Jenjang ini bertalian dengan nilai yang dikenakan siswa terhadap suatu objek, fenomena, atau tingkah laku tertentu.

d. Organisasi (Organization). Tingkat ini berhubungan dengan menyatukan nilai-nilai yang berbeda, menyelesaikan/memcahkan konflik diantara nilai-nilai itu, dan mulai membentuk satu sistem nilai yang konsisten secara internal.

e. Karakteristik dengan suatu nilai atau kompleks nilai. Pada jenjang ini individu memiliki sistem nilai yang mengontrol tingkah lakunya untuk suatu waktu yang cukup lama sehingga membentuk karakteristik pola hidup.

f. Pengukuran ranah psikomotorik. Pengukuran ranah psikomotorik dilakukan terhadap hasil-hasil belajar yang berupa penampilan. Namun demikian biasanya pengukuran ranah ini disatukan atau dimulai dengan pengukuran ranah kognitif sekaligus. Misalanya penampilan dalam menggunakan termometer diukur mulai dri pengetahuan mereka mengenai alat tersebut, pemahaman tentang alat dan penggunaannya (aplikasi), kemudian baru cara menggunakananya dalam bentuk keterampilan. Untuk pengukuran yang terakhir ini harus diperinci anatar lain: cara memegang, cara meletakkan, cara membaca angka, cara mengembalikan kedalam tempatnya, dan sebagainya. Ini semua tergantung dari kehendak kita, asal tujuan pengukuran dapat terapai (Arikunto, 2003). 


\section{SIMPULAN}

Evaluasi sebagai suatu kegiatan mengumpulkan data dan informasi mengenai kemampuan belajar siswa, untuk menilai sudah sejauh mana program telah berjalan, dan juga sebagai suatu alat untuk menentukan apakah tujuan pendidikan dan proses pembelajaran dalam mengembangkan ilmu pengetahuan telah berlangsung sebagaimana mestinya. Evaluasi bertujuan untuk mengetahui tingkat pencapaian siswa dalam suatu proses pembelajaran, sekaligus untuk memahami siswa sampai sejauh mana dapat memberikan bantuan terhadap kekurangan-kekurangan siswa, dengan tujuan menempatkan siswa pada situasi pembelajaran yang lebih tepat sesuai dengan tingkat kemampuan yang dimilikinya. Sedangkan fungsi evaluasi untuk membantu proses, kemajuan dan perkembangan hasil belajar peserta didik secara berkesinambungan, dan sekaligus dapat mengetahui kemampuan dan kelemahan siswa pada bidang studi tertentu, sekaligus dapat memberikan informasi kepada orang tua wali siswa mengenai penentuan kenaikan kelas atau penentuan kelulusan siswa.

\section{DAFTAR PUSTAKA}

Abdullah, Ramli. 2015. Urgensi Penilaian Hasil Belajar Berbasis Kelas Mata Pelajaran Ips Di Madrasah Tsanawiyah Lantanida Journal, Vol. 3 No. 2.

Arifin, Zainal. 2014. Evaluasi Pembelajaran Bandung: PT Remaja Rosdakarya.

Arikunto, Suharsimi. 2003. Dasar-Dasar Evaluasi Pendidikan. Jakarta: PT Bumi Aksara .

Daryanto, M.H. 2001. Evaluasi Pendidikan Jakarta: PT Rineka Cipta

https://www.academia.edu/28592716/Makalah_Evaluasi_dan_Hasil_Belajar Mahirah, 2017. Evaluasi Belajar Peserta Didik (Siswa). Jurnal Idaarah, Vol. I, No. 2, Desember.

Silverius, Suke. 1991. Evaluasi belajar dan umpan balik. Jakarta: PT Grasindo. 